\title{
Temporal Morphogenesis of Herpes Simplex Virus Type 1-Infected and Brefeldin A-Treated Human Fibroblasts
}

\author{
Helle L. Jensen ${ }^{1,2}$ and Bodil Norrild ${ }^{1}$ \\ ${ }^{1}$ The Protein Laboratory, Institute of Molecular Pathology, University of Copenhagen, Copenhagen, Denmark \\ ${ }^{2}$ The Department of Pathology, Gentofte University Hospital, Copenhagen, Denmark \\ Accepted February 21, 2002
}

\begin{abstract}
Background: Insights in the herpesvirus-cell interactions are of general cell biology interest, especially to studies of intracellular transport, and of considerable significance in the efforts to generate drugs, vaccines, and gene therapy. However, the pathway of virus particle egress and maturation is a contentious issue.

Materials and Methods: The intracellular transport was inhibited in cultured herpes simplex virus type l (HSV-1) infected human fibroblasts by brefeldin A (BFA). The virus-cell interactions including the viral envelopment, transport of HSV-1 virions, and transport of viral glycoprotein $\mathrm{D}(\mathrm{gD}-1)$ and glycoprotein $\mathrm{C}(\mathrm{gC}-1)$ were studied by titration assay, immunoblot, immunofluorescence light microscopy, and immunogold electron microscopy of cryosections.

Results: gD-1 and gC-1 were synthesized and normally transported to the plasma membranes of untreated HSV-1 infected host cells. BFA ( $1 \mu \mathrm{g} / \mathrm{ml}$ medium) effectively blocked the transport of the glycoproteins to the plasma
\end{abstract}

membranes and affected the tubulin and vimentin of the cytoskeleton. Viral particles and glycoproteins accumulated in the perinuclear space and the endoplasmic reticulum of BFA treated cells. Withdrawal of BFA influence up to $9 \mathrm{hr}$ resulted in restored tubulin and vimentin, transport of glycoproteins to the plasma membranes, and steady release of infectious viral particles to the extracellular space superior to the cellular assembly of new virions. The ultrastructural data presented support that the primary envelopment of viral particles occur at the nuclear membranes containing immature glycoproteins followed by multiple de-envelopments and re-envelopments of the virions during the transport and maturation in the endoplasmic reticulum and the Golgi complex.

Conclusions: BFA-induced changes include the cytoskeleton with significant effect on HSV-1 maturation and egress. The data support a multiple-step envelopment of HSV-1 in a common pathway of glycoprotein synthesis and virion egress.

\section{Introduction}

Human herpesviruses diseases are becoming of increasing medical significance because the viruses are widespread in the populations with influence on the AIDS epidemic expansion and because of an increase in the number of patients receiving organ transplants (1). Herpesvirus-cell interactions have enormous potential significance in our understanding of the regulation of cell functions and conversion of cells from the normal to abnormal and malignant states. Glycoproteins are, in general, sequentially transported through the cis-, medial-, and transcompartments of the Golgi apparatus and finally expressed on the cell surface (2-4). Thus, the Golgi complex plays an important role in sorting and trafficking proteins. Herpesviruses shut off host macromolecular synthesis in productively infected cells to favor viral assembly (5). The herpes simplex virus (HSV) genome is linear double-stranded DNA of $152 \mathrm{kbp}$, which encodes at least 15 membrane

Correspondence and reprint requests should be addressed to: Helle L. Jensen, MD, The Protein Laboratory, University of Copenhagen, The Panum Institute, Bldg. 6.2., Blegdamsvej 3C, DK-2200 Copenhagen N, Denmark. Phone: +45 3532 7307; fax: +4535360116 . proteins including 11 identified glycoproteins $\mathrm{gB}$, $\mathrm{gC}, \mathrm{gD}, \mathrm{gE}, \mathrm{gG}, \mathrm{gH}, \mathrm{gI}, \mathrm{gJ}, \mathrm{gK}, \mathrm{gL}$, and gM (5-7). The view of HSV glycoprotein functions, based on in vitro experiments, are generally valid in vivo (8). Glycoprotein $\mathrm{gC}$ is dispensable for HSV replication in cell culture, but $\mathrm{gD}$ is required $(5,9,10)$. The $\mathrm{N}$-terminal region of gC mediates binding of HSV to the primary cell-surface receptor heparan sulphate, and $\mathrm{gD}$ is required for postattachment entry of virus into cells (7-10). The nuclear fraction of HSV1-infected cells is associated predominantly with high-mannose precursor forms among others of both gC and gD, but fully glycosylated forms are also detectable in them (11-13). The exact pathway by which HSV enters and leaves the cell is still poorly understood $(14,15)$. There is general agreement that herpesviruses bud at the inner nuclear membrane $(5,13,16)$, but the subsequent cytoplasmic maturation events remain a matter of controversy $(13,16)$. Several studies have linked viral infection and morphologic changes with alterations in the cytoskeletal network (17-21). Nii (1) called for detailed examinations of virus infected cells by immunoelectron microscopy using various monoclonal antibodies to reach the proper conclusion concerning the egress of herpesviruses. 
The studies described here are parts of a larger effort to determine the envelopment and transport of HSV-1 virions together with the viral glycoproteins and virus-cell interactions. Unfortunately $(16,22)$, an ultrastructural time sequence study is clear cut only during the initial stages of viral synthesis because subsequent asynchrony becomes apparent with many viral stages visible at one time within any given cell. As an example, the viral envelopment is very rapid, which is why budding viral particles were seldom met and definitive envelopment at the nuclear membranes was not encountered in our previous electron microscopy studies $(16,23)$. Further, distinct labeling of the nuclear membranes was demonstrated only with the gD antibodies, but the gC was under the level of detection by the immunogold cryosection electron microscopy method used $(16,23)$. One possible approach will be to further analyze the maturation of viral particles in cells with brefeldin A (BFA)-blocked and BFA-released transport, which is the subject of the present report. BFA, an antiviral antibiotic isolated from the fungus Eupenicillium brefeldianum (24), causes rapid redistribution of Golgi proteins into the endoplasmic reticulum, leaving no definable Golgi apparatus, and blocks transport of proteins into post-Golgi compartments in the cell (25-27). The BFA-effected inhibition of protein secretion is at least partially reversible and involves the cytoskeleton $(20,28)$.

\section{Materials and Methods}

Reagents, Antibodies, and Conjugates

Unless indicated, all chemicals were purchased from Merck (Darmstadt, Germany).

The monoclonal antibodies HCl (29) against HSV gC (MW 130.000), and both Fd 138-80 (30) and DL6 (31-33) against HSV gD (MW 60.000) are of subclass IgG2a. $\mathrm{HCl}$ is type specific. The gD antibodies are type common and DL6 detects residues 272-279 of a continuous epitope. The monoclonal anti- $\beta$-tubulin (no. N 357), monoclonal anti-actin (no. N 350), monoclonal anti-vimentin (no. RPN 1102), and goatanti-rabbit (GAR) IgG conjugated to 5-nm colloidal gold particles (GAR-G5, no. RPN 420) or 15-nm colloidal gold particles (GAR-G15, no. RPN 422) were purchased from Amersham (Amersham, UK). The monoclonal anti-human T-cell UCHLl (no. M 742), affinity-purified (34) rabbit anti-mouse (RAM) immunoglobulins (no. Z 259), fluorescein isothiocyanate (FITC)-conjugated RAM (no. F 232), biotinylated RAM (no. E 354), and horseradish peroxidase coupled streptavidin (no. P 397) were obtained from DAKO (Glostrup, Denmark). Human IgG was acquired from The State Serum Institute (Copenhagen, Denmark).

\section{General Remarks}

Duplicates of slides and grids were made and the immunolabelings were repeated at least twice.
Working conditions for growth and maintenance of human fibroblasts, infection with HSV-1, cell preparations, and immunolabelings followed techniques detailed earlier $(21,23,35,36)$. In each experiment, about 300 cells were examined in the electron microscope.

\section{Viruses}

Viral stocks of HSV-1 strain F (37) were replaced every 6 months and made phenotypically concordant by two passages in MRC- 5 cells below passage 35 (23).

Cells

Human embryonic lung fibroblasts (MRC-5) delivered at passage 26-28 (no. 02-021; Flow Laboratories, McLean, VA, USA) were propagated as monolayer cultures at $37^{\circ} \mathrm{C}$ in essential basal medium Eagle (modified) with Earle's salts (no. 14-000-49) (EBME; Flow Laboratories) supplemented with nonessential amino acids, sodium bicarbonate, glutamine, antibiotics, $10 \%$ heat inactivated fetal bovine serum (FBS), and $5 \% \mathrm{CO}_{2}$. The cell cultures were proved mycoplasma-free and the cells were passaged twice a week just at confluence $(23,35)$.

\section{Frozen Cell Preparations for Microscopy}

At passage 33, the just confluent MRC-5 cells in $25 \mathrm{~cm}^{2}$ culture flasks were exposed to 30 plaque forming units (pfu) of virus per cell in EBME medium with $1 \%$ FBS at $37^{\circ} \mathrm{C}$. After $1 \mathrm{hr}$ of adsorption, the inoculum containing unabsorbed virus was removed. The cells were washed briefly in $5 \mathrm{ml}$ EBME containing $1 \%$ FBS and $1 \mu \mathrm{g}$ BFA (no. 1347136, Boehringer Mannheim Biochemica, Mannheim, Germany) per milliliter and exactly $5 \mathrm{ml}$ of fresh medium containing BFA was added for $12 \mathrm{hr}$ at $37^{\circ} \mathrm{C}$. The medium was removed and cells not intended for reversibility studies were washed briefly in sterile $37^{\circ} \mathrm{C}$ PBS and fixed. Following BFA treatment, cells intended for reversibility examination were rinsed three times and constantly moved about $10 \mathrm{sec}$ in $5 \mathrm{ml}$ of $37^{\circ} \mathrm{C}$ PBS to remove BFA and then incubated at $37^{\circ} \mathrm{C}$ with exactly $5 \mathrm{ml}$ of fresh EBME containing $1 \%$ FBS for $5 \mathrm{~min}, 15 \mathrm{~min}, 30 \mathrm{~min}$, $60 \mathrm{~min}, 3 \mathrm{hr}, 6 \mathrm{hr}$, and $9 \mathrm{hr}$, respectively, and fixed.

The cells were fixed at room temperature for 10 min in PBS-buffered freshly prepared 3\% PFA (paraformaldehyde, no. P 026; TAAB Laboratories Equipment, Aldermaston, UK) added 2\% GA (glutaraldehyde, no. G 002; TAAB Laboratories Equipment). The cells were then embedded in PBS-buffered $20 \%$ gelatin, cryoprotected in $2.3 \mathrm{M}$ PBS-buffered sucrose with 1\% PFA, frozen, and stored in liquid nitrogen. Semithin cryosections for light microscopy and ultrathin cryosections for electron microscopy were cut in a RMC MT 6000 XL cryoultramicrotome. Cryosections about 500 nm thick were put on air-dried, dustless object microscope slides after the slides were rinsed in $1 \% \mathrm{HCl}$ in $70 \%$ 
alcohol and distilled water. About $100 \mathrm{~nm}$ thick cryosections were put on formvar-covered and carbon coated 200-mesh nickel grids.

\section{Immunofluorescence Light Microscopy}

The low-fading immunofluorescence two-layer indirect labeling with propidium iodide contrast was performed as described previously $(20,35)$. This method appears to be reproducible by blinded duplicates of slides in multiple experiments scored semiquantitatively by two observers (21).

\section{Immunogold Cryosection Electron Microscopy}

The details of the applied three-layer indirect immunogold monolabeling procedure have earlier been presented (23). In brief, the sections were washed with PBS and $0.02 \mathrm{M}$ of glycine in PBS was applied for $10 \mathrm{~min}$ to inactivate any remaining aldehyde. In between washes, the incubations were carried out for $45 \mathrm{~min}$ with the primary antibody (Fd 138-80, DL6, HC1, or anti- $\beta$-tubulin), affinitypurified RAM $2.5 \mu \mathrm{g} / \mathrm{ml}$ for $30 \mathrm{~min}$ and GAR-G5 for $20 \mathrm{~min}$. In cases of double immunogold labeling (36), inactivation of antigen-combining sites of secondary anti-IgG antibodies was performed with PBS-buffered freshly prepared 3\% PFA $+2 \%$ GA for $2 \mathrm{hr}$ at room temperature and the second labeling sequence rendered visible by GAR-G15. After wash, the reaction was postfixed with $2 \%$ GA for $10 \mathrm{~min}$ and the sections were stained by a solution of icecold $1.35 \%$ methyl cellulose containing $0.4 \%$ aqueous uranyl acetate. The ultrathin sections were examined in a Zeiss electron microscope 900, operating at $80 \mathrm{kV}$, and photomicrographs were taken on Agfa Scientia EM film. These techniques allow safe semiquantitative estimations of labeling, but quantitative analysis is deprecated $(23,36)$.

\section{Determination of Time-Related Titers of Medium- and Cell-Associated Virions}

In parallel, HSV-1-infected MRC-5 fibroblasts were grown in $25-\mathrm{cm}^{2}$ cell culture flasks $\left(1.5 \times 10^{6}\right.$ cells $)$ and treated with BFA as described. These cells were carefully scraped off the culture flasks with a plastic policeman, centrifuged at $1500 \mathrm{rpm}$ for $10 \mathrm{~min}$, the pellet was resuspended in $500 \mu \mathrm{l}$ of EBME with $1 \%$ FBS and the cells were broken by ultrasonic treatment and stored as previously described (20). The viral titers were determined by plaque assay (37) after $1 \mathrm{hr}$ adsorption of $1 \mathrm{ml}$ diluted viral suspension in $\log _{10}$ steps on confluent Vero cell (no. 03-230, Flow Laboratories) monolayers (passage 137-144) overlaid with medium containing $0.2 \%$ human IgG. The plaques were fixed with formaldehyde and stained with crystal violet.

\section{Cell Extracts}

Two hundred microliters of BFA-treated, released, or untreated cell suspensions were sonicated again, and $10 \mu \mathrm{l}$ of $10 \% \mathrm{NP}-40$ were added to each.

\section{Protein Quantitation}

The protein concentration was measured in each cell extract diluted 1:25, 1:50, and 1:100. Protein measurements were performed with a Micro BCA protein assay reagent kit (no. 23235; Pierce, Rockford, IL, USA) according to the instructions given by the manufacturer.

\section{Immunoblots}

Fifty-microliter cell suspensions of HSV-1 infected fibroblasts $12 \mathrm{hr}$ postinfection (hpi) without BFA treatment or BFA treated as described, and with release for $5 \mathrm{~min}, 15 \mathrm{~min}, 30 \mathrm{~min}, 60 \mathrm{~min}, 3 \mathrm{hr}, 6 \mathrm{hr}$, and $9 \mathrm{hr}$, were each supplemented with $10 \mu \mathrm{l}$ of a $6 \times$ concentrated loading buffer used for SDSPAGE analysis (38). For each sample, a volume corresponding to $4 \mu \mathrm{g}$ of protein was loaded on a $10 \%$ PAGE gel. The electrophoresis was run for $30 \mathrm{~min}$ at $50 \mathrm{~V}$ followed by $\mathrm{l} \mathrm{hr}$ at $100 \mathrm{~V}$. The proteins were electroblotted onto an ethanol activated polyvinylidene difluoride membrane (no. 1620 184, Bio-Rad, Hercules, CA, USA) at $0.2 \mathrm{~mA} / \mathrm{cm}^{2}$ for $2 \mathrm{hr}$. Afterward, the membranes were incubated for $\mathrm{l} \mathrm{hr}$ at room temperature with monoclonals to gD-1 (Fd 138-80), actin, $\beta$-tubulin, or vimentin. The monoclonal antibodies were diluted in PBS with $1 \%$ skim milk and $0.05 \%$ Tween 20 . Incubation followed with biotinylated RAM, horseradish peroxidase coupled streptavidin, and immunodetection was performed with ECL Western blotting detection reagents (no. RPN 2106, Amersham).

\section{Controls}

The lowest concentration of BFA ( $1 \mu \mathrm{g} / \mathrm{ml}, 3 \mu \mathrm{g} / \mathrm{ml}$, and $5 \mu \mathrm{g} / \mathrm{ml}$ were tested) and the optimum time (0 and $2 \mathrm{hr}$ after adsorption of virus) for addition of BFA was determined for the ability to inhibit the cellular transport completely and afterward revoke the effect by washout. Untreated or BFA-treated non-virus-infected (MOCK) cells and untreated HSV-1 infected cells 12 hpi were compared with BFA-treated and released HSV-1-infected cells. Immunocytochemical controls were carried out by omission of the primary or secondary antibody and replacement with buffer or type-matched unrelated monoclonal antibody UCHLl. Labeling with anti- $\beta$-tubulin served as a positive control.

\section{Results}

Time-Related Titration of Infectious Virions of Medium and Cells

The inhibition of virus formation by BFA treatment was convincing but not complete at $12 \mathrm{hpi}$ (Table 1 ). BFA reduced the pfu production of infectious virions by a factor of 100 and resulted in $0.2 \%$ infectious virions in the medium compared to unperturbed HSV-1-infected cells. When the BFA had been removed and the cells rinsed, the infectious 
Table 1. Time-related yields of secreted and cell-associated infectivity from unperturbed, BFA-treated, and BFA-released HSV-1-infected cells

\begin{tabular}{|c|c|c|c|c|}
\hline & $\begin{array}{l}\text { pfu/ml } \\
\text { Medium }\end{array}$ & $\begin{array}{l}\text { pfu/ml Cell } \\
\text { Suspension }\end{array}$ & $\begin{array}{c}\text { Total } \\
\text { Virions }\end{array}$ & $\begin{array}{c}\text { Total } \\
\text { Virus/Cell }\end{array}$ \\
\hline -BFA, 6 hpi & $0.80 \times 10^{5}$ & $3.59 \times 10^{7}$ & $1.83 \times 10^{7}$ & 12.17 \\
\hline- BFA, 12 hpi & $19.45 \times 10^{5}$ & $18.25 \times 10^{7}$ & $9.90 \times 10^{7}$ & 66.02 \\
\hline -BFA, 18 hpi & $67.44 \times 10^{5}$ & $31.00 \times 10^{7}$ & $18.20 \times 10^{7}$ & 121.00 \\
\hline- BFA, 22 hpi & $69.14 \times 10^{5}$ & $27.30 \times 10^{7}$ & $16.42 \times 10^{7}$ & 109.43 \\
\hline+ BFA, 12 hpi & $45.80 \times 10^{2}$ & $15.00 \times 10^{5}$ & $7.66 \times 10^{5}$ & 0.51 \\
\hline$+\mathrm{BFA}$, removed for $5 \mathrm{~min}$ & $3.35 \times 10^{2}$ & $7.70 \times 10^{5}$ & $3.86 \times 10^{5}$ & 0.26 \\
\hline$+\mathrm{BFA}$, removed for $15 \mathrm{~min}$ & $7.54 \times 10^{2}$ & $12.58 \times 10^{5}$ & $6.32 \times 10^{5}$ & 0.42 \\
\hline$+\mathrm{BFA}$, removed for $30 \mathrm{~min}$ & $9.16 \times 10^{2}$ & $12.05 \times 10^{5}$ & $6.06 \times 10^{5}$ & 0.40 \\
\hline$+\mathrm{BFA}$, removed for $60 \mathrm{~min}$ & $11.58 \times 10^{2}$ & $15.78 \times 10^{5}$ & $7.94 \times 10^{5}$ & 0.53 \\
\hline$+\mathrm{BFA}$, removed for $3 \mathrm{hr}$ & $17.00 \times 10^{2}$ & $9.50 \times 10^{5}$ & $4.82 \times 10^{5}$ & 0.32 \\
\hline$+\mathrm{BFA}$, removed for $6 \mathrm{hr}$ & $13.67 \times 10^{2}$ & $25.40 \times 10^{5}$ & $12.76 \times 10^{5}$ & 0.85 \\
\hline$+\mathrm{BFA}$, removed for $9 \mathrm{hr}$ & $30.67 \times 10^{2}$ & $4.00 \times 10^{5}$ & $2.12 \times 10^{5}$ & 0.14 \\
\hline
\end{tabular}

The plaque forming units $(\mathrm{pfu} / \mathrm{ml})$ of the media $(5 \mathrm{ml})$ and cell suspensions $(0.5 \mathrm{ml})$ from $25-\mathrm{cm}^{2}$ cultures $\left(1.5 \times 10^{6}\right.$ cells $)$ of $\mathrm{HSV}$ l-infected MRC-5 cells (-BFA) harvested at different times after infection (hpi) and after removal of BFA in samples treated with BFA for $12 \mathrm{hpi}$. The titers are corrected for infectious virus particles in the PBS wash samples.

number of virus particles set free to the medium rose by a factor of 10 from 5 min to $9 \mathrm{hr}$ after removal. However, the calculated total virions or virus produced per cell showed no significant production of infectious virions through $9 \mathrm{hr}$ release (Table 1). On the contrary, the greatest increase of infectious virions set free to the medium from 6-9 hr was at the expense of cell-associated infectious virus particles.

The reproducibility of the titration assay seemed to be reasonable. Thus, statistical analysis (Wilcoxon signed-rank test) did not reveal difference between the counted infectious virus particles in duplicate parallel samples of two series of experiments $(p>0.05)$.

\section{Protein Quantitation}

The coefficient of variation concerning protein concentration of non-BFA-treated HSV-1 infected cells at $6,12,18$, and 22 hpi were 5.1 and 12.56 when comparing untreated cells at $12 \mathrm{hpi}$ with BFA-treated cells for $12 \mathrm{hpi}$, and BFA-released cells up to $9 \mathrm{hr}$.

\section{Immunoblots}

Western blot analysis was carried out to determine the relative changes in the quantity of the viral glycoprotein $\mathrm{gD}$ and the cytoskeleton proteins in BFA treated and released HSV-1-infected samples (Fig. 1). The quantity of actin remained nearly unchanged; vimentin decreased close to $3 \mathrm{hr}$ after BFA washout. Tubulin accumulated and the level of gD decreased with increasing time from 60 min after removal of BFA (Fig. 1).
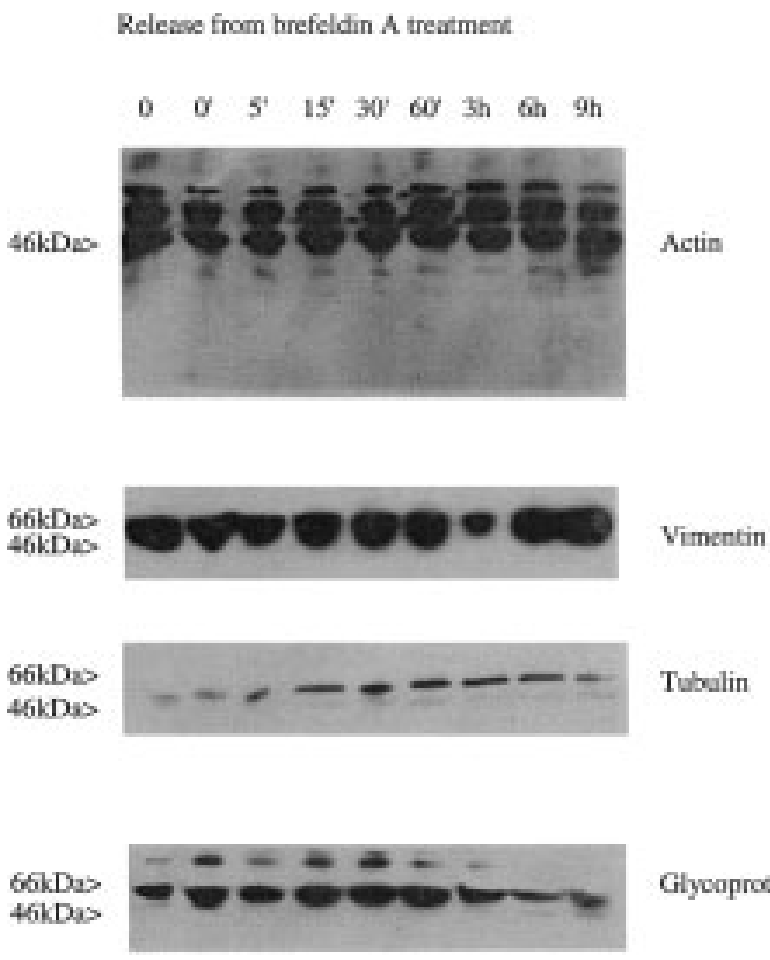

Glyouprosein D

Fig. 1. Immunoblot detected actin, vimentin, tubulin, and gD-1 in HSV-1-infected fibroblasts without BFA treatment (0), treated with BFA $\left(0^{\prime}\right)$, and after removal of BFA for 5, 15, 30, and $60 \mathrm{~min}$, and 3, 6, and $9 \mathrm{hr}$. 


\section{Morphology}

Untreated MOCK cells (Fig. 3A) were long and slender, with regular nuclei and insignificant vac- uolization of the cytoplasm. Confirming our previous results $(16,23)$ infection with HSV-1 (Figs. 2A, $2 \mathrm{~B}$ and $3 \mathrm{C}$ ) revealed time-dependent rounding and
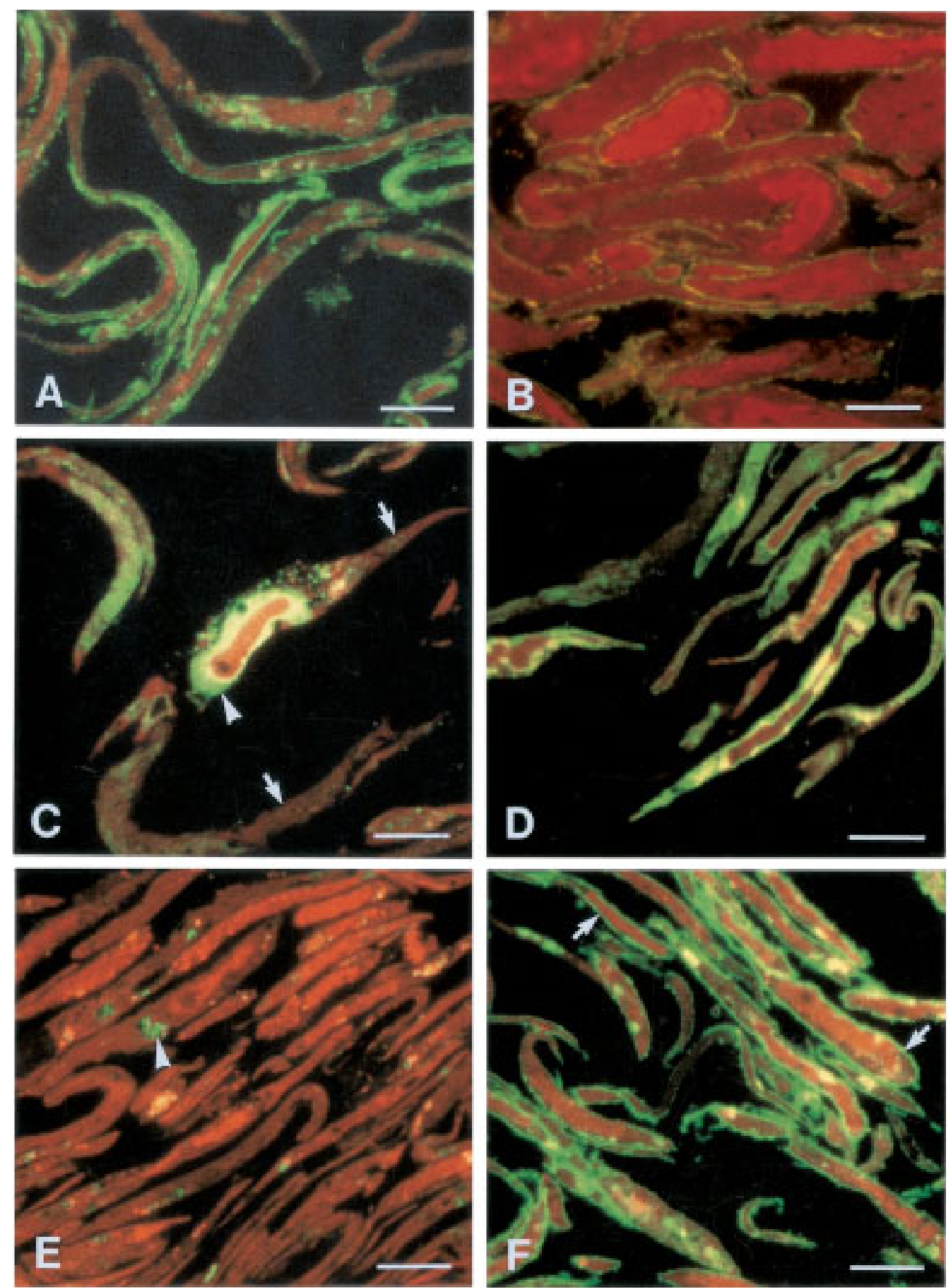

Fig. 2. Immunofluorescence in semithin cryosections of HSV-1 infected and gD-1 (A, C, D, F) or gC-1 (B, E) labeled human fibroblasts showing the effects of BFA (C) and the reversibility of BFA influence (D, E, F). The plasma membranes (arrows) were unlabeled and the glycoproteins piled up in a gigantic perinuclear space (arrowhead) in some BFA-treated cells (C). In the cytoplasm, scattered spots of glycoproteins were presented in unperturbed and BFA-treated cells up to 15 min following release, after which the glycoproteins were transported widespread to the cytoplasm in a reticular pattern (D). Nearly all glycoproteins accumulated in Golgi-like areas after removal of BFA for $3 \mathrm{hr}$ (E, arrowhead), although some labeled adhesion areas could be identified. When BFA was washed away for $9 \mathrm{hr}$, the labeling of the plasma membranes (arrows) were nearly restored (F). Bars: A-F $=10 \mu \mathrm{m}$. 

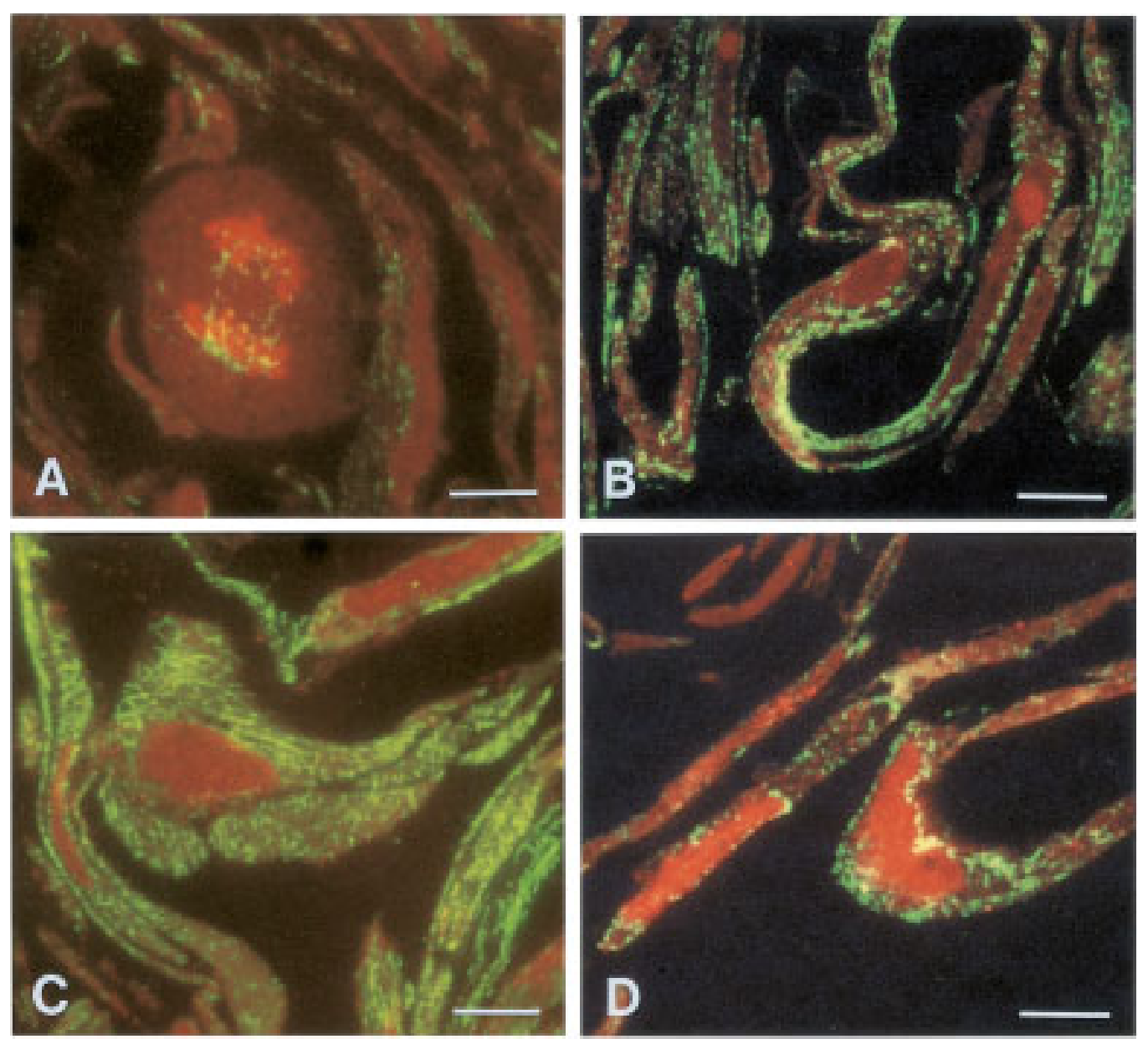

Fig. 3. Immunofluorescence labeling of tubulin in semithin cryosections of MOCK (A, B) with a presented mitosis (A) and HSV-1 (C, D) infected fibroblasts. HSV-1-infected cells (C) showed increased labeling of short fibers as well as some globules of tubulin. Globules of tubulin were dominant in BFA-treated cells (B, D) and accumulated around the nuclei and close to the plasma membrane, especially in HSV-1-infected cells (D). Bars: A-D $=10 \mu \mathrm{m}$.

steadily increasing size of the cells, the cell surface and nuclei became irregular with margination of the nuclear chromatin (Fig. 4A), the nuclear pores became prominent, the perinuclear space became dilated, and the cytoplasm was vacuolated in part, caused by dilation of the endoplasmic reticulum and the Golgi sacs. The initial envelopment of capsids took place at the nuclear membranes, but definitive ligation of capsids wrapped in membrane were not encountered. Viral particles were transported from the perinuclear space through membrane-bound vesicles, the endoplasmic reticulum (Fig. $4 \mathrm{~A}$ ), and the Golgi complex to the cell surface. By this route, the envelope of the virions appeared to be exchanged several times.

Although well-infected with HSV, many of the BFA-treated cells for 12 hpi (Figs. 2C and 3D) were like MOCK cells-long and slender-and the cytoplasm appeared reticular and variably vacuolated. Ultrastructural BFA effects were unremarkable or variable dilatation of the perinuclear space (Fig. 6A) and the endoplasmic reticulum (Fig. 6B) giving an extensive tubular network (Figs. 5A and 5B). Also, the nuclear pores were prominent (Fig. 6D). Enveloped and naked virions accumulated in the perinuclear space between the inner and outer nuclear membrane (Figs. 4B, 6A, 6B and 6D). Capsids were variably accumulated in the nuclei and queued up at the inner nuclear membrane (Fig. 5A). Many virions were transported to the endoplasmic reticulum (Figs. 4B, 5B, 6B, 7A, 7B and 7C), but not behind the level of recognizable Golgi complexes in unreleased cells. The Golgi complexes were changed by the HSV infection and further disintegrated by BFA. Reduplicated nuclear membranes (Figs. 5A, 6B, 6C and 6D), budding of viral particles in the nuclear membranes (Figs. 6B, 6C, and 6D), reduplicated membranes of endoplasmic reticulum (Figs. 5B, 7A, 7B and 7C) together with re-envelopments in Golgi areas and endoplasmic reticulum (Figs. 5B, 7A and 7C) were observed more often in BFA-treated cells than in unperturbed control cells. When BFA was removed, the morphology steadily changed partially in the direction of non-BFA-treated cells. After BFA 

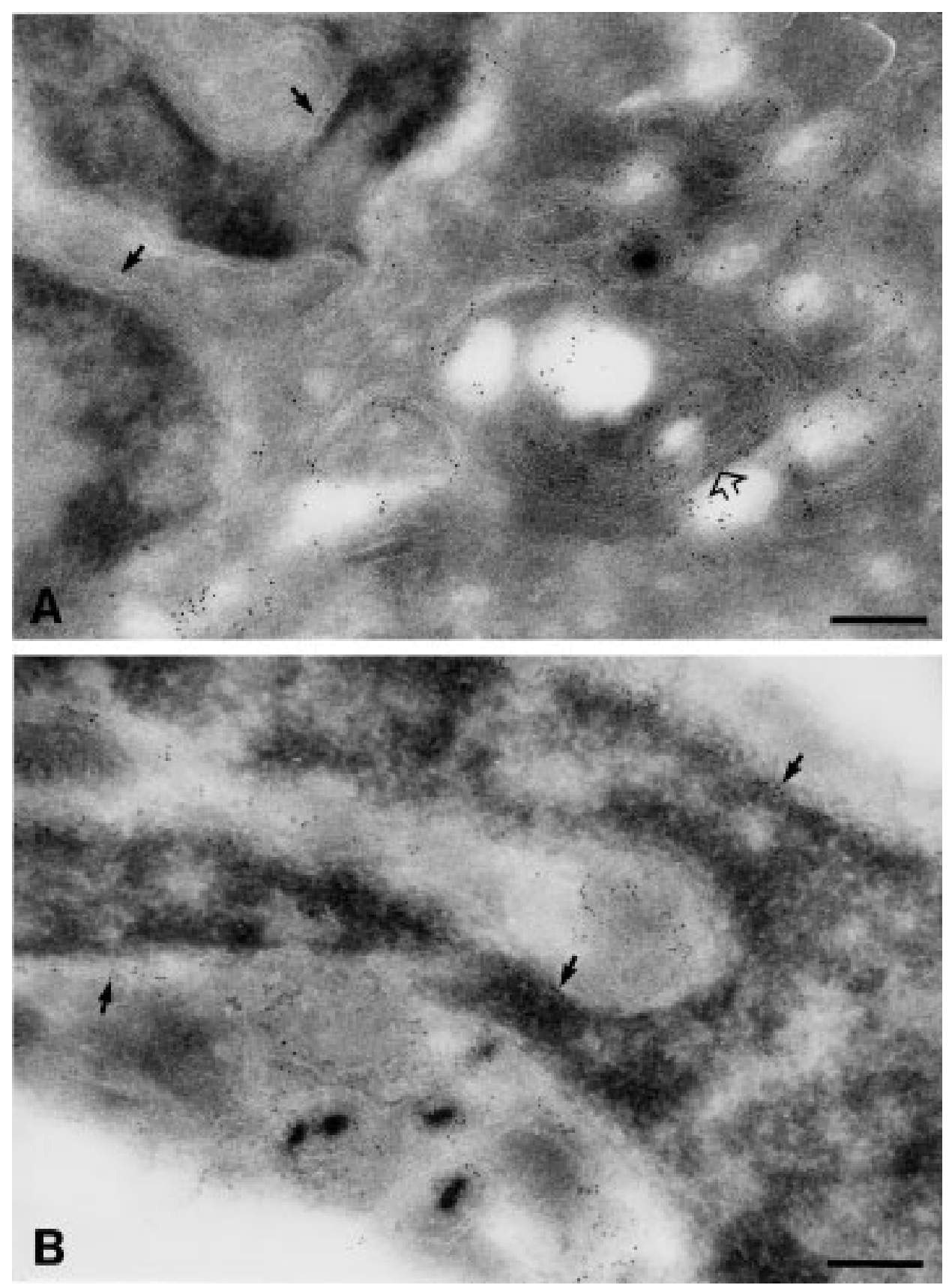

Fig. 4. Ultrathin cryosections of HSV-1-infected fibroblasts immunolabeled for gC-1 with HC1 and GAR-G5. Convincing gC-1 was not visible in the nuclear membranes (arrows) without BFA treatment (A), although the endoplasmic reticulum and the Golgi complex (empty arrow) were strongly reactive for gC-1. In BFA-treated cells (B, here released for $15 \mathrm{~min}$ ), the gC-1 accumulated in the nuclear membranes (arrows). Bars: $\mathrm{A}=0.3 \mu \mathrm{m} ; \mathrm{B}=0.25 \mu \mathrm{m}$.

washout for $30 \mathrm{~min}$, envelopment activity in the nuclear membranes was maximal, but many unenveloped capsids were also met in the perinuclear space (Fig. 6A), the endoplasmic reticulum (Fig. 5B), and in the cytoplasm (Figs. 6A, 7A, 7B and 7C). This activity slowed down after $3 \mathrm{hr}$ removal of BFA and the nuclei were exhausted for capsids beyond $6 \mathrm{hr}$ release (Figs. 6D and 7B). So, the synthesis of capsids was modest or nil, but the envelopment at the nuclear membranes was preserved during BFA washout. Viral egress at the plasma membranes was noted only a few times. Extracellular virus particles were extremely rare and often zero in BFA-affected cells and after washout up to $3 \mathrm{hr}$ but increased slowly afterward.

\section{Immunofluorescence Light Microscopy of Semithin Cryosections}

Indirect immunofluorescence labeling of non-BFAtreated and HSV-1-infected MRC-5 cells 12 hpi 

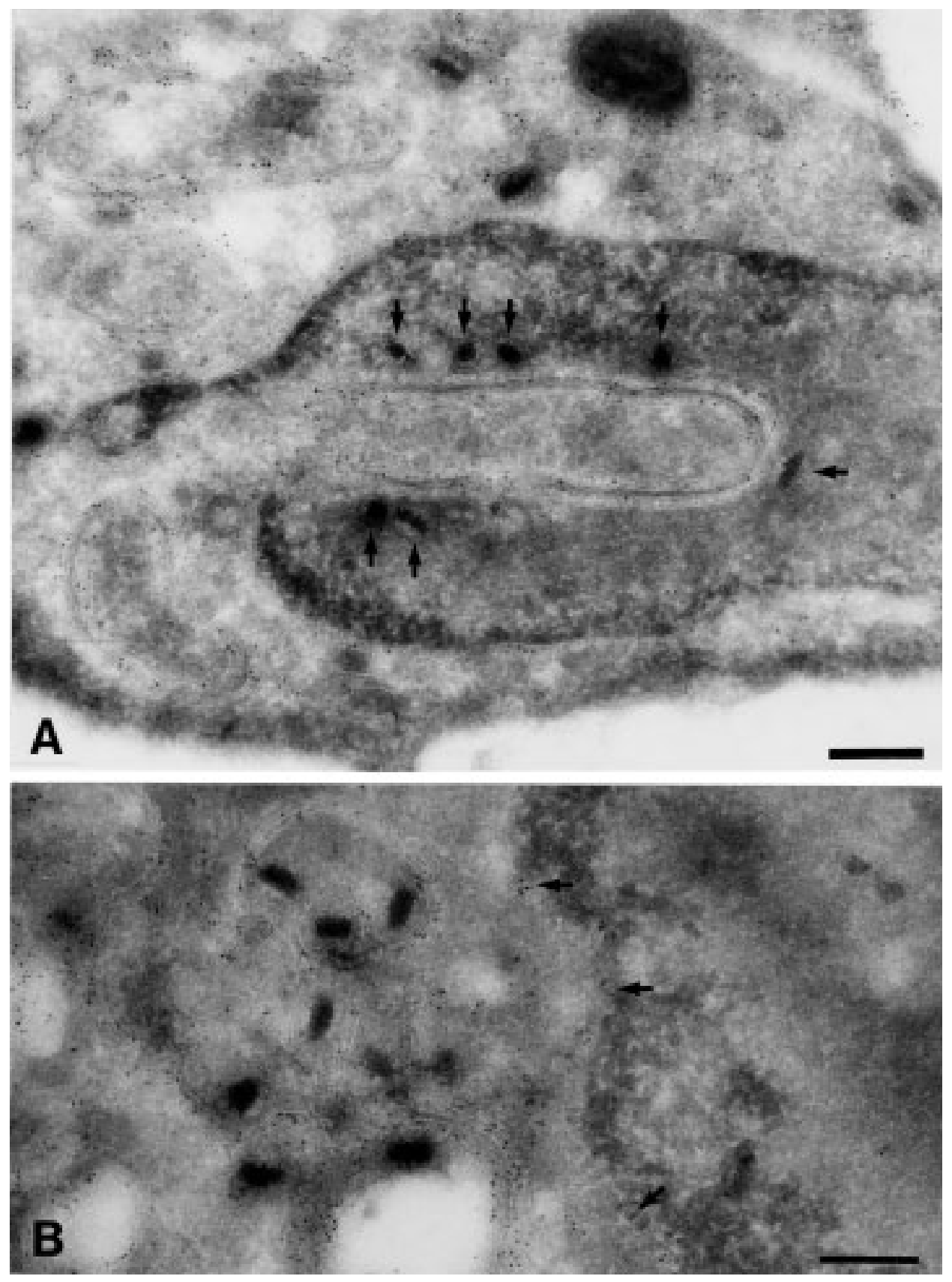

Fig. 5. Ultrathin cryosections of HSV-1-infected and BFA-treated fibroblasts with BFA effects removed for 5 min (A) and $3 \mathrm{hr}$ (B). The BFA clearly causes the capsids (arrows) to line up along reduplicated nuclear membranes intensely labeled with DL6 and GAR-G5 for gD-1 (A). Three hours after BFA removal (B), the nuclear membranes still contained gD-1 (arrows), but the capsids were moved from the nucleus to the gD-1-labeled endoplasmic reticulum. Bars: $\mathrm{A}-\mathrm{B}=0.25 \mu \mathrm{m}$.

showed diffuse infection and estimated labeling of more than $75 \%$ of the cells. The gD-1 (Fig. 2A) of these cells was localized to the nuclear membranes, Golgilike compartments near the nucleus, and the plasma membranes. However, gC-1 (Fig. 2B) was delayed compared to gD-1, mainly disclosed on the plasma membrane and never in the nuclear membranes.

Confirming previous results of whole cell preparations (20), the semithin sections of BFA-treated and HSV-1-infected cells revealed focal gD-1 or $\mathrm{gC}-1$ labeling of fewer than $50 \%$ of the cells. When BFA was washed away, the glycoprotein labeling increased up to $75 \%$ of the cells released for $9 \mathrm{hr}$. The gD-1 labeling (Fig. 2C) was heavy in the perinuclear area, and probably especially in the dilated perinuclear space including the nuclear membranes. As opposed to cryosections of untreated cells, some BFAtreated cells revealed a granular, but never a convincing continuous pattern of $\mathrm{gC}-1$ localized to the area of nuclear membranes. The plasma membranes were 

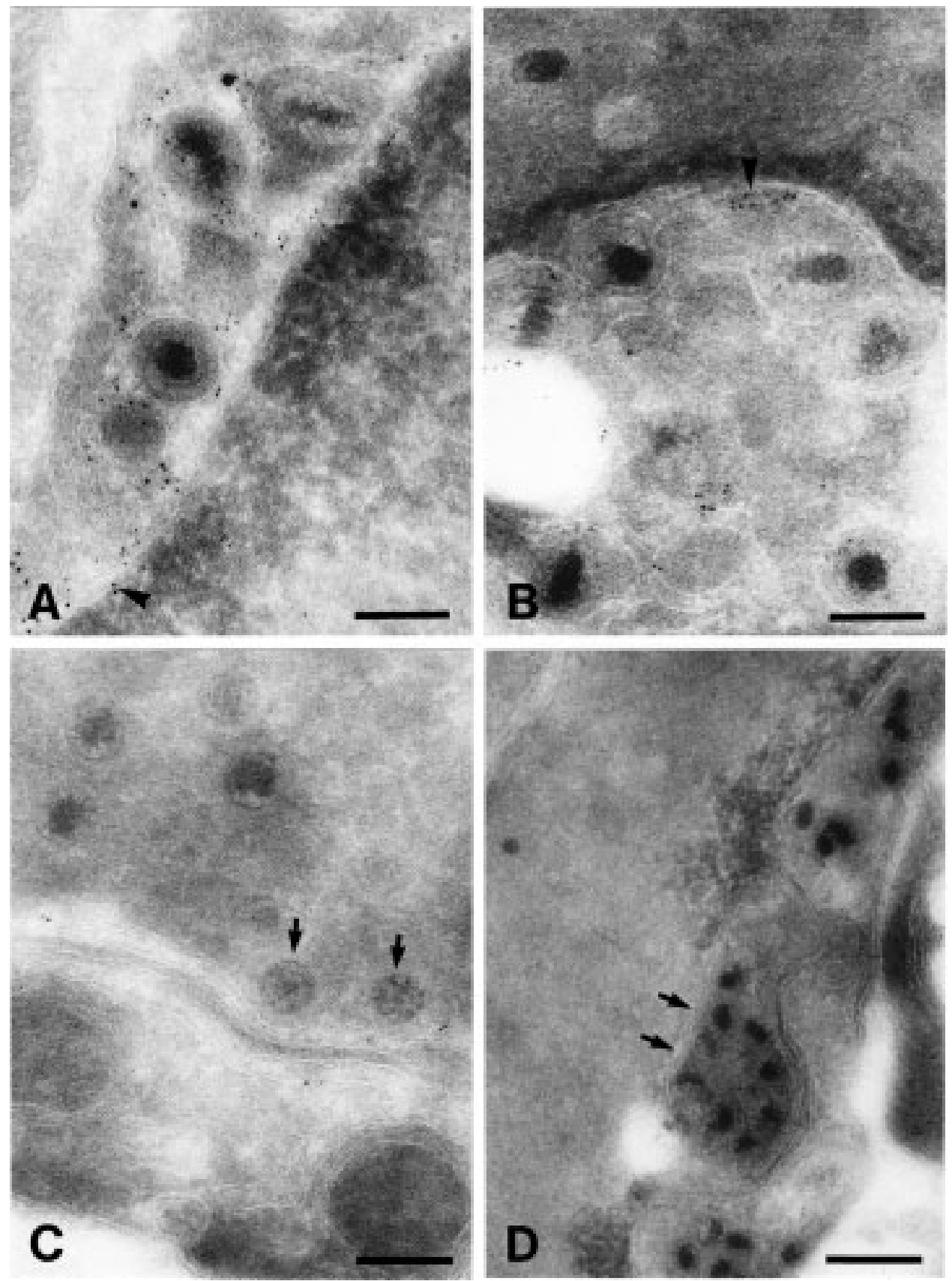

Fig. 6. Ultrathin cryosections of HSV-1-infected fibroblasts treated with BFA (A, B) and after removal of BFA for 30 min (C) and 6 hr (D). Both gD-1 (A and C) and gC-1 (B) were demonstrable in the nuclear membranes (arrowheads). The capsids accumulated at reduplicated nuclear membranes (arrows C, D). After $6 \mathrm{hr}$ washout, the nuclei were nearly exhausted of capsids (D). Tubulin was marked with GAR-G15 (A) or GAR-G5 (D). Bars: A-C $=0.15 \mu \mathrm{m}$; D $=0.4 \mu \mathrm{m}$.

unlabeled for both glycoproteins (Fig. 2C). The pattern of tubulin in BFA-treated cells was mainly globules at the expense of fibers, although the changes of MOCK cells often were insignificant, but the tubulin accumulated close to the nuclei when HSV-1 infected (Figs. 3A, 3B, 3C, and 3D).

As in whole cells (20), the semithin cryosections demonstrated some distinct dots of cytoplasmic gD1 close to the nuclei (Fig. 2C) in BFA-treated cells and more widespread cytoplasmic labeling after 5 min washout. When BFA was removed for more than $15 \mathrm{~min}$, the cytoplasmic growing label was reticular and probably localized to the endoplasmic reticulum (Fig. 2D). Also at that time, pools of gD-1 were identified in the perinuclear area, but after $3 \mathrm{hr}$ removal of BFA, all gD-1 was transported from the perinuclear area to the cytoplasmic compartments (Fig. 2E). The nuclear membranes appeared 

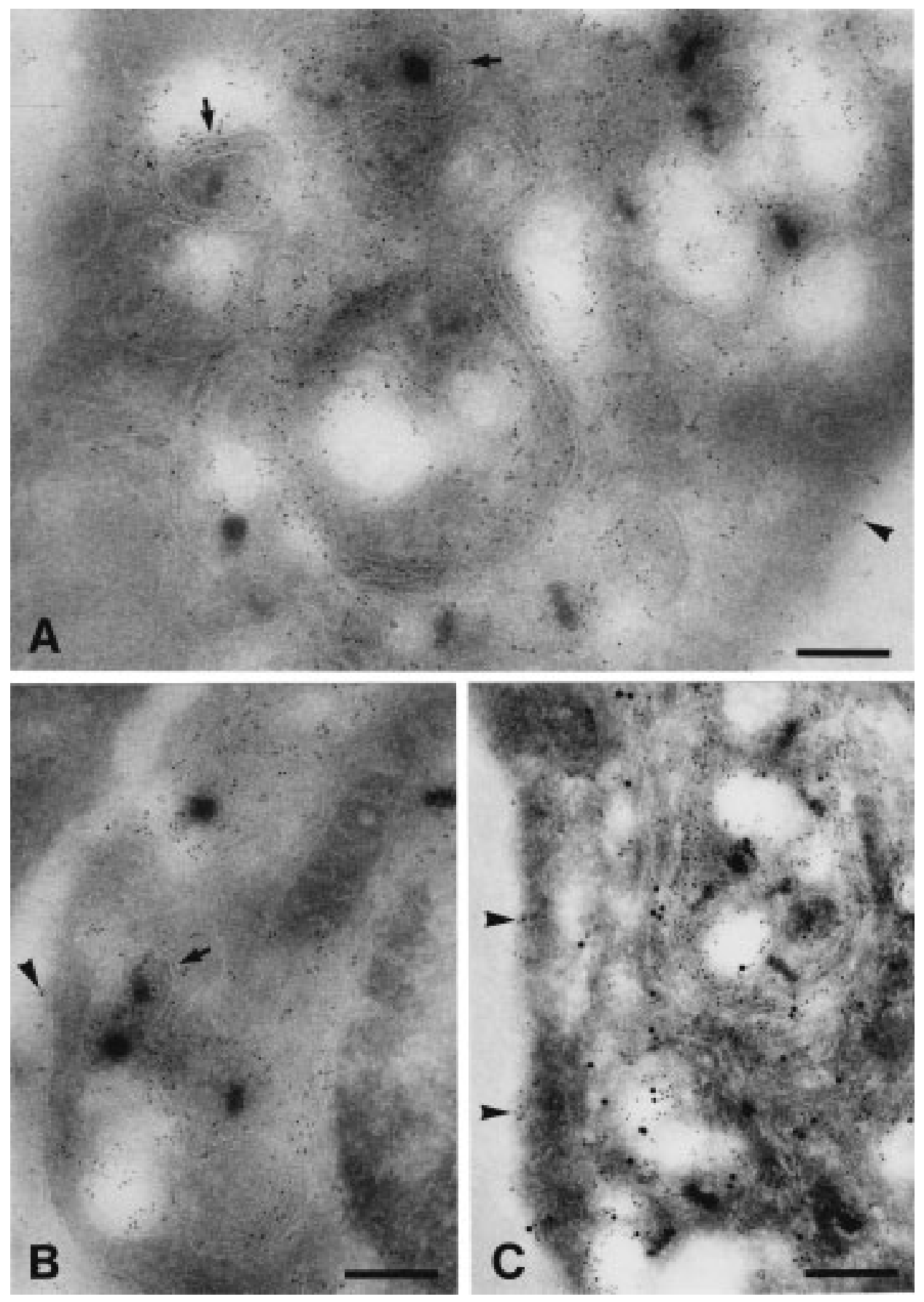

Fig. 7. Mono-immunogold- (A, B) and double-immunogold- (C) labeled ultrathin cryosections of HSV-1-infected and BFAtreated cells released for $6 \mathrm{hr}(\mathrm{A}, \mathrm{B})$ and $9 \mathrm{hr}(\mathrm{C})$. Glycoprotein D was detected with DL6 and GAR-G5 and tubulin was identified with GAR-G15. The nuclear membranes (B), endoplasmic reticulum (A, B, C), and plasma membranes (arrowheads A, B, C) were plainly reactive for gD-1. In the cytoplasmic compartment after $9 \mathrm{hr}$ washout of BFA (C); tubulin surrounded the endoplasmic reticulum and was mixed with the glycoprotein. Several naked capsids were met in the cytoplasmic compartment, and envelopment occurred in the endoplasmic reticulum (arrows A, B). Bars: A-C $=0.25 \mu \mathrm{m}$.

unlabeled, and heavy accumulation of glycoproteins were observed in Golgi-like areas at $3 \mathrm{hr}$ release (Fig. 2E). When BFA was removed for $60 \mathrm{~min}$, both glycoproteins were identified in the adhesion areas, and at $6 \mathrm{hr}$ release, the labeling of the plasma membranes was convincing. The gD-1 labeling of the nuclear membranes was partly regenerated and gD- 1 transported widespread to the plasma membrane at 9 hr BFA washout (Fig. 2F). The transport of gC- 1 after removal of BFA was similar, but as in untreated cells with some delay. The labeling of tubulin was reduced, but the pattern of tubulin, although 
delicate, was nearly normalized 6-9 hr after removal of BFA.

\section{Immunogold Cryosection Electron Microscopy}

The BFA affected the glycoproteins parallel with the ultrastructural morphologic changes of HSV1-infected cells. Considerable accumulation of gD1 in the nuclear membranes (Figs. 5A and 6A) was most conspicuous in BFA-treated cells and after short washout together with labeled enveloped viral particles in the perinuclear space. Further, contrary to untreated cells, the BFA caused the $\mathrm{gC}-1$ to be detected in the nuclear membranes (Figs. 4B and $6 \mathrm{~B})$. With increasing time of release to more than $30 \mathrm{~min}$, the labeling of glycoproteins in the nuclear membranes was somewhat reduced and the gC was with certainty by the method used once again under the level of detection at $9 \mathrm{hr}$ release. Although variably, also during BFA release, all samples revealed strong labeling of gD-1 and later $\mathrm{gC}-1$ in the endoplasmic reticulum, in the Golgi areas, and on the surface of some cytoplasmic enveloped viral particles (Figs. 4B, 5A, 5B, 7A, 7B, and $7 C$ ). Both labeled, unlabeled, naked and enveloped viral particles were encountered in the cytoplasmic compartments. The intensity of labeling increased in Golgi areas with time after BFA removal. The plasma membranes were unlabeled in BFA-treated cells (Figs. 6A and 6B). However, withdrawal of BFA influence reestablished the transport of both glycoproteins to the plasma membranes clearly detectable at $3 \mathrm{hr}$ release and afterward with increasing intensity (Figs. 7A, 7B, and 7C). Clusters of tubulin in place of fibers were noted close to nuclear membranes, at viral particles and in cytoplasmic membranes of HSVinfected cells both with (Figs. 6D and 7C) and without BFA treatment. The tubulin was pressed in BFA-treated cells by the dilated endoplasmic reticulum resulting in intimate mixture of tubulin and glycoproteins (Fig. 7C). During release, the pattern of tubulin was partly normalized with more fibers and tubulin closer to the plasma membrane, but the intensity of labeling appeared reduced in accord with the immunofluorescence results, and although immunoblot showed increased level of tubulin.

\section{Controls}

Inhibition of cellular transport by $1 \mu \mathrm{g}$ of BFA $/ \mathrm{ml}$ medium added after adsorption of virus was preferred because the inhibition as with $3 \mu \mathrm{g}$ of BFA $/ \mathrm{ml}$ and $5 \mu \mathrm{g}$ of BFA $/ \mathrm{ml}$ was convincing although not complete, the cellular effects tolerable, and the release protracted after removal of BFA compared to cells with BFA added 2 hpi. Furthermore, when BFA was added $2 \mathrm{hpi}$, the titers of released infectious virions fluctuated and appeared unreliable or reflecting virions with different maturation at the addition of BFA.
Immunostaining of MOCK cells and omission of the primary or secondary antibody in HSV-1infected cells were all gD-1- and gC-1-negative.

\section{Discussion}

The correlation between the social behavior of HSV1-infected cells and the modification of cellular membranes for the virion to be enveloped were noticed in 1968 by Ejercito et al. (37). The pathway by which HSV-1 enters and leaves the cell exploits the normal metabolic reactions of the host cell, but the exact virus-cell interactions are still controversial. The fungal metabolite BFA $(26,27)$ has wide significance for studies of membrane traffic and protein processing in eukaryotic cells, but the mechanisms of action are not finally demonstrated. Intracellular transport of virus particles and viral glycoproteins after addition of BFA to the host cells have been studied earlier in the herpesviruses HSV-1 (20,39-42), human cytomegalovirus (43), varicellazoster (44), and pseudorabies (45). The effects of BFA on vesicular stomatitis virus $G$ protein, a wellcharacterized model integral membrane protein, are described in several reports (46-49). Further, the BFA effects on retrovirus-transformed murine erythroleukemia cells (28), influenza virus (50), rubella virus (51), and poliovirus (52) have been examined. The motivations for the presented BFA study were to a) accumulate HSV-1 glycoproteins, and especially gC, detectable by immunogold cryosection electron microscopy; b) examine the transport of accumulated viral particles and glycoproteins when BFA was washed away; and c) further examine the significance of tubulin in virion morphogenesis and virus-cell interactions.

As shown in the present study by several concordant methods, BFA significantly inhibited the transport of viral glycoproteins and the release of infectious particles from HSV-1-infected fibroblasts, which confirms previous studies $(20,39,40)$. The inhibition of $1 \mu \mathrm{g}$ of BFA $/ \mathrm{ml}$ medium added for $12 \mathrm{hr}$ after virus adsorption was significant with an extracellular virus yield of only $0.2 \%$ compared to untreated cells; cell-associated infectious virus particles were also reduced to $0.8 \%$ in drug-treated cells. In Vero cells, the yield of infectious virions decreased exponentially with increasing concentrations of BFA and the inhibition was immediate (41). The presented morphologic BFA effects on cells and virus propagation were in accord with previous observations $(39,40)$, and the effects were not fully reversible. The effects of BFA included variably dilated perinuclear space and endoplasmic reticulum with piled up virions and glycoproteins, disintegrated Golgi apparatus, some cytoplasmic vacuolization, and changes of tubulin favoring globules accumulating around the nuclei. It seems clear that glycoproteins are found on cytoplasmic membranes and are most abundant on endoplasmic reticulum, 
Golgi, and virions, which supports the suggestion that the virion gains the final envelope in the cytoplasm. Nucleocapsids assemble in the nucleus and bud through the inner nuclear membrane. Phospholipid composition of extracellular HSV differs from the nuclei isolated from infected cells and contains higher concentrations of lipids typically enriched in the Golgi apparatus and plasma membrane (14). Ultrastructural studies have previously identified gD-1 in the nuclear membranes $(16,21,23,36,53)$. The presented BFA inhibition allowed gC-1 to be detected in the nuclear membranes and additional studies confirming the multistep envelopment process (16) of viral particles at the inner nuclear membrane, in the endoplasmic reticulum and finally in the Golgi complex. Koyama and Uchida (41) suggested a BFAsensitive and a BFA-insensitive pathway for the formation of enveloped HSV-1 particles and presented data consistent with a major envelopment site of HSV-1 nucleocapsids and formation of infectious progeny virus in the Golgi complex of the BFA-sensitive route. In addition, Browne et al. (54) presented data consistent with a similar route of HSV exit by constructing a recombinant virus, in which the expression of the essential gH is restricted to the inner nuclear membrane and endoplasmic reticulum. However, Stannard et al. (53) favored the model whereby capsids are enveloped only once at the inner nuclear membrane.

Assembly and release of infectious virus particles were very fast, and in unit of time the majority were set free within 5 min after removal of BFA. The ultrastructural identification of virions in both the perinuclear space and in the endoplasmic reticulum of BFA-treated cells may definitely confirm the block of BFA to be located in the Golgi complex or to be caused by fast transport during brief wash and too slow fixation. By titration assay, only infectious viral particles are detected and nothing is known about incomplete viral particles. Electron micrographs disclosed that the nuclei were exhausted for capsids during the studied 9-hr recovery after drug treatment. Cheung et al. (39) and Chatterjee and Sarkar (40) also noticed that the infectious virus concentration inside BFA-treated cells did not increase substantially during the 8-18 hpi period. These results imply an intact envelopment with predominantly high-mannose immature glycoproteins $(11-13,53)$ at nuclear membranes and maturing transport through the endoplasmic reticulum and Golgi complex, but that the assembly of new capsids suffered in BFAtreated cells. However, Koyama and Uchida (41) did not find the yield of nucleocapsids markedly affected by the drug at concentrations not more than $0.2 \mu \mathrm{g} \mathrm{BFA} / \mathrm{ml}$. Also, Dasgupta and Wilson (42) demonstrated that procapsids matured and packaged the viral genome normally, but remained nonenveloped and failed to exit the nucleus at the shortterm presence of $5 \mu \mathrm{g} \mathrm{BFA} / \mathrm{ml}$. Chatterjee and Sarkar (40) observed complete restoration of infectious
HSV-1 particles intracellularly and extracellularly after the removal of BFA in low concentration. BFA brought along immature forms of viral glycoproteins, but removal of BFA resulted in a reorganization of the Golgi complex and formation of fully glycosylated proteins (40). Only fully processed gC and gD are detected in purified virions from the culture medium $(11,12)$. Anyway, fully glycosylated glycoproteins are not required for viral infectivity (55), but are needed in the transport of virions to the extracellular space (13).

The glycoproteins are trimmed and new sugars are normally added in the cis-, medial-, and transcompartments of the Golgi apparatus, and finally the mature viral proteins are expressed on the cell surface $(2,4)$. In several cell lines, the half-time for transport of proteins from the endoplasmic reticulum to the cell surface has been determined to be between 5 and $20 \mathrm{~min}$ (56). BFA is a lipophilic, heterocyclic lactone that, in agreement with the present results, acts after $15 \mathrm{~min}$ by inducing redistribution of Golgi proteins into the endoplasmic reticulum and transport in the opposite direction less than 15 min after removal of BFA $(57,58)$. More than $0.05 \mu \mathrm{g} / \mathrm{ml}(0.18 \mu \mathrm{M})$ BFA impedes protein transport from the endoplasmic reticulum to the Golgi apparatus $(40,59)$, and the Golgi carbohydrate processing enzymes are redistributed to a distended endoplasmic reticulum $(26,27,46,58)$. The Golgi complex is disintegrated together with the endoplasmic reticulum, giving an extensive tubular network within 10 min of BFA treatment (60). The Golgi enzymes are completely recovered from the endoplasmic reticulum after $10 \mathrm{~min}(46)$, and normal appearance of the Golgi complex has been observed after 30 min (28) to $2 \mathrm{hr}(58)$ after removal of the drug. When BFA was washed away for $3 \mathrm{hr}$ in the present study, the vimentin decreased and glycoproteins accumulated in Golgi zones, which indicates maximum final glycosylation at this point. In addition, the glycoproteins appeared first in adhesion areas of the plasma membranes, indicating an intercellular signal function. Enough immature glycoprotein was synthesized in the presence of BFA for $12 \mathrm{hr}$ to a 4-fold reduction of the time for the glycoproteins to be detected in the plasma membrane after removal of BFA (20). Only correctly folded proteins are as a rule transported further in the secretory pathway (4), which is why it is extraordinary that some studies $(53,61)$ have unexpectedly identified intranuclear glycoproteins, and immature forms of $\mathrm{gB}, \mathrm{gC}$, and $\mathrm{gD}$ have been detected on the surface of BFA-treated cells $(40)$.

Supporting previous studies $(26,39,40,45,57)$, the incomplete reversibility of the BFA effects as shown here by immunofluorescence, immunogold electron microscopy, and titration might be due to cell type, BFA concentration, time for drug application, incomplete removal of BFA, and maximal liberation after more than $9 \mathrm{hr}$ BFA washout. The procedure of BFA washout was only rarely stated in the literature 
$(20,59)$, which is essential because assembly and transport of virions are very fast. Although it has been reported (28) that BFA render the cells sensitive to damage by fixation the morphologic changes are most likely of cytotoxic character, also because the changes were partly reversible when BFA was washed away. There were lumpy nuclei (20) and reduced protein in the present study, which also point toward a cytotoxic effect of BFA. However, in spite of the BFA inhibition, mitosis was encountered both in MOCK and HSV-1-infected cell cultures (20), probably all in uninfected cells, because HSVinfected cells cannot divide (62). This observation indicates that BFA affects tubulin, but does not completely destroy the function. In fact, neither is protein synthesis required for actin depolymerization in the cytoskeleton (18). There are conflicting reports concerning the influence of BFA on the total protein synthesis $(25,41,47,50,58,63)$. Nonetheless, in defiance of protein concentrations with different coefficients of variation, the immunoblot results of BFAtreated and -released cells were similar to time-related changes in gD and cytoskeleton components of non-BFA-treated HSV-1-infected cells (16). Microtubule-organizing centers appeared to be more numerous in BFA-treated cells than in controls, especially during recovery (28). The present immunoblot showed accumulation of tubulin after removal of BFA, while tubulin microscopically became delicate and seemed reduced. This apparent inconsistency may be caused by changed tubulin architecture with antigenic determinant readily detected by blot with the antibody used. Other studies $(40,43)$ refuted cytotoxicity as a cause of BFA findings, although the cytomegalovirus DNA replication was prevented and the cytoskeleton was not examined. Viral DNA synthesis in HSV-infected fibroblast was found to be completely unimpaired by BFA (43).

Confirming previous studies $(20,64)$ both the HSV infection presented and the BFA influenced the tubulin of microtubules. After HSV-1 penetration of the host cell, it has been shown that incoming viral capsids in the cytosol normally bind to dynein in microtubules that propel them from the cell periphery to the nucleus (65). Most of the extranuclear capsids are associated with microtubules, and the transport dependence on microtubules increases with larger distance between the plasma membrane and the nucleus (65). The HSV-1 tegument protein VP22 is colocalized with cellular microtubules and exhibits the properties of a classical microtubule-associated protein during both transfection and infection (66). Furthermore, tubulin is involved in normal intracellular transport of HSV glycoproteins and infectious virions (19-21). However, at least in axons, the traffic of nucleocapsids coated with tegument are separated from the transport of glycoproteins (67). Microtubules have been observed fragmented and the organization altered with reformation of microtubules into bundles surrounding the nucleus of HSV-infected cells (64). Changes of tubulin may indicate dysfunction of the microtubules and be responsible for the detected enlargement of the perinuclear space, dilated endoplasmic reticulum, and the disassembly of the Golgi complex in BFA-treated cells. The disassembled Golgi complex form long tubular structures that are likely to utilize cytoskeleton components including microtubules for their formation and movement, and behave like and rapidly fuse with the endoplasmic reticulum (58). Oddly enough, a more disrupted microfilament network of the cytoskeleton of early human cytomegalovirus infection, another herpesvirus, appears to favor infectious viral production (18), but this was not the case for measles virus (17). We observed some reduction of total protein together with quantitative and microscopic, partially reversible changes of tubulin when HSV-1-infected cells were treated with BFA and when BFA was washed away. The tubulin fibers were normalized 6-9 hr after removal of the drug in agreement with the period of most infectious virus particles set free to the medium. Although washout of BFA increased the relative quantity of tubulin, the cytoskeleton action might be affected and might be an explanation of incomplete release of infectious virus particles and impaired production of capsids. However, our previous immunofluorescence studies of whole cells (20) showed normalization of tubulin fibers after wash-out of BFA prior to the detection of gD-1 labeled vesicles reaching the plasma membrane, indicating that tubulin is involved in the intracellular transport of viral glycoproteins. Basically, these data are consistent with the concept that longterm BFA treatment can be cytotoxic with reduced cell division $(20,24)$, dose dependent decreased protein synthesis (63) and causing disrupted microtubule structure and function $(25,47)$. However, Dasgupta and Wilson (42) recently demonstrated that the immediate effect of BFA on HSV replication is to inhibit budding at the inner nuclear membrane. Although reports are conflicting, the observed changes of the tubulin pattern in the present study and our previous study (20) are likely to be part of the BFA action.

In conclusion, the present data confirm our previous observations $(16,20)$ and suggest that a) only fully glycosylated mature glycoproteins are transported to the plasma membranes; $b$ ) the transport of nonessential $\mathrm{gC}-1$ is similar but delayed compared to transport of essential gD-1 in both unperturbed cells and BFA-treated cells; c) the primary envelopment of virions occurs at the nuclear membranes containing immature glycoproteins; d) multiple de-envelopments and re-envelopments in the endoplasmic reticulum and the Golgi complex cause maturation of viral particles; e) the virus-cell interactions and BFA effects involve tubulin in the cytoskeleton; and f) the BFA effects are not completely reversible. Taken together, our data suggest a common 
pathway of virion egress and glycoprotein export. Furthermore, our data confirm the de-envelopment/ re-envelopment process of HSV-1 maturation and supplement two recent studies $(68,69)$ of several alphaherpesviruses with similar morphogenesis in all virus-cell systems analyzed.

\section{Acknowledgments}

This work was supported by grants from the Danish Cancer Society and by funds from the Health Insurance "danmark," Frands Køhler Nielsen and wife, Erik Hørslev and wife, Birgit Hørslev, E. Danielsen and wife, Anna and Jakob Jakobsen, Valdemar and Thyra Foersom, Torben and Alice Frimodt, Aage Bang, and the LEO Foundation.

We are grateful to G.H. Cohen and R.J. Eisenberg (University of Pennsylvania, Philadelphia), S. Chatterjee (University of Alabama, Birmingham), and L. Pereira (University of California, San Francisco) for generous gifts of monoclonal antibodies. Cryosection and electron microscopy facilities were kindly made available by Professor O. Norén and Professor H. Sjöström (University of Copenhagen, Denmark).

\section{References}

1. Nii S. (1992) Electron microscopic study on the development of herpesviruses. J. Electron. Microsc. 41: 414-423.

2. Stryer L. (1981) Biochemistry, 2nd ed. New York: Freeman.

3. Tufaro F, Snider MD, McKnight SL. (1987) Identification and characterization of a mouse cell mutant defective in the intracellular transport of glycoproteins. J. Cell. Biol. 105: 647-657.

4. Doms RW, Lamb RA, Rose JK, Helenius A. (1993) Folding and assembly of viral membrane proteins. Virology 193: 545-562.

5. Roizman B, Sears AE. (1996) Herpes simplex viruses and their replication. In Fields BN, Knipe DM, Howley PM, et al. (eds). Fields Virology, 3rd ed. Philadelphia: Lippincott-Raven; 2231-2295.

6. Ward PL, Campadelli-Fiume G, Avitabile E, Roizman B. (1994) Localization and putative function of the $U_{L} 20$ membrane protein in cells infected with herpes simplex virus 1 . J. Virol. 68: 7406-7417.

7. Rajcáni J, Vojvodová A. (1998) The role of herpes simplex virus glycoproteins in the virus replication cycle. Acta Virol. 42: $103-118$.

8. Minson AC. (1994) Interactions of herpes simplex viruses with the host cell. Biochem. Soc. Trans. 22: 298-301.

9. Ligas MW, Johnson DC. (1988) A herpes simplex virus mutant in which glycoprotein D sequences are replaced by $\beta$ galactosidase sequences binds to but is unable to penetrate into cells. J. Virol. 62: 1486-1494.

10. Olofsson S. (1992) Carbohydrates in herpesvirus infections. APMIS Suppl. 27 100: 84-95.

11. Compton T, Courtney RJ. (1984) Virus-specific glycoproteins associated with the nuclear fraction of herpes simplex virus type 1-infected cells. J. Virol. 49: 594-597.

12. Compton T, Courtney RJ. (1984) Synthesis, processing, and localization of herpes simplex virus type 1 glycoproteins, $\mathrm{gB}$ and gC. In Rapp F (ed). Herpesvirus. New York, NY, USA, Alan R. Liss; 343-358.

13. Di Lazzaro C, Campadelli-Fiume G, Torrisi MR. (1995) Intermediate forms of glycoconjugates are present in the envelope of herpes simplex virions during their transport along the exocytic pathway. Virology 214: 619-623.
14. van Genderen IL, Brandimarti R, Torrisi MR, Campadelli G, van Meer G. (1994) The phospholipid composition of extracellular herpes simplex virions differs from that of host cell nuclei. Virology 200: 831-836.

15. Enquist LW, Husak PJ, Banfield BW, Smith GA. (1998) Infection and spread of alphaherpesviruses in the nervous system. Adv. Virus Res. 51: 237-347.

16. Jensen HL, Norrild B. (2002) Morphologic, immunohistochemical, immunologic, ultrastructural, and time-related study of herpes simplex virus type 1-infected cultured human fibroblasts. AIMM, 10: 71-81.

17. Bedows E, Rao KMK, Welsh MJ. (1983) Fate of microfilaments in Vero cells infected with measles virus and herpes simplex virus type 1. Mol. Cell Biol. 3: 712-719.

18. Jones NL, Lewis JC, Kilpatrick BA. (1986) Cytoskeletal disruption during human cytomegalovirus infection of human lung fibroblasts. Eur. J. Cell Biol. 41: 304-312.

19. Norrild B, Lehto V-P, Virtanen I. (1986) Organization of cytoskeleton elements during herpes simplex virus type 1 infection of human fibroblasts: an immunofluorescence study. J. Gen. Virol. 67: 97-105.

20. Jensen HL, Rygaard J, Norrild B. (1995) A time-related study of brefeldin A effects in HSV-1 infected cultured human fibroblasts. APMIS 103: 530-539.

21. Jensen HL, Norrild B. (2000) The effects of cell passages on the cell morphology and the outcome of herpes simplex virus type 1 infection. J. Virol. Meth. 84: 139-152.

22. Nii S, Morgan C, Rose HM. (1968) Electron microscopy of herpes simplex virus. II. Sequence of development. J. Virol. 2: 517-536.

23. Jensen HL, Norrild B. (1998) Herpes simplex virus type 1-infected human embryonic lung cells studied by optimized immunogold cryosection electron microscopy. J. Histochem. Cytochem. 46: 487-496.

24. von Härri E, Loeffler W, Sigg HP, Stähelin H, Tamm C. (1963) Über die isolierung neuer stoffwechselprodukte aus Penicillium brefeldianum Dodge. Helv. Chim. Acta 46: 1235-1243.

25. Misumi Y, Misumi Y, Miki K, Takatsuki A, Tamura G, Ikehara Y. (1986) Novel blockade by brefeldin A of intracellular transport of secretory proteins in cultured rat hepatocytes. J. Biol. Chem. 261: 11398-11403.

26. Pelham HRB. (1991) Multiple targets for brefeldin A. Cell 67: 449-451.

27. Klausner RD, Donaldson JG, Lippincott-Schwartz J. (1992) Brefeldin A: insights into the control of membrane traffic and organelle structure. J. Cell Biol. 116: 1071-1080.

28. Ulmer JB, Palade GE. (1991) Effects of brefeldin A on the Golgi complex, endoplasmic reticulum and viral envelope glycoproteins in murine erythroleukemia cells. Eur. J. Cell Biol. 54: 38-53.

29. Pereira L, Klassen T, Baringer JR. (1980) Type-common and type-specific monoclonal antibody to herpes simplex virus type 1. Infect. Immun. 29: 724-732.

30. Koga J, Chatterjee S, Whitley RJ. (1986) Studies on herpes simplex virus type 1 glycoproteins using monoclonal antibodies. Virology 151: 385-389.

31. Eisenberg RJ, Long D, Ponce de Leon M, et al. (1985) Localization of epitopes of herpes simplex virus type 1 glycoprotein D. J. Virol. 53: 634-644.

32. Isola VJ, Eisenberg RJ, Siebert GR, Heilman CJ, Wilcox WC, Cohen GH. (1989) Fine mapping of antigenic site II of herpes simplex virus glycoprotein D. J. Virol. 63: 2325-2334.

33. Lausch RN, Staats H, Oakes JE, Cohen GH, Eisenberg RJ. (1991) Prevention of herpes keratitis by monoclonal antibodies specific for discontinuous and continuous epitopes on glycoprotein D. Invest. Ophthalmol. Vis. Sci. 32: 2735-2740.

34. Grøndahl-Hansen J, Ralfkiær E, Nielsen LS, Kristensen P Frentz G, Danø K. (1987) Immunohistochemical localization of urokinase- and tissue-type plasminogen activators in psoriatic skin. J. Invest. Dermatol. 88: 28-32.

35. Jensen H, Broholm N, Norrild B. (1995) Low-fading immunofluorescence with propidium iodide contrast compared with immunogold light microscopy in whole cells and semithin cryosections. J. Histochem. Cytochem. 43: 507-513. 
36. Jensen HL, Norrild B. (1999) Easy and reliable doubleimmunogold labelling of herpes simplex virus type-1 infected cells using primary monoclonal antibodies and studied by cryosection electron microscopy. Histochem. J. 31: 525-533.

37. Ejercito PM, Kieff ED, Roizman B. (1968) Characterization of herpes simplex virus strains differing in their effects on social behaviour of infected cells. J. Gen. Virol. 2: 357-364.

38. Schägger H, von Jagow G. (1987) Tricine-sodium dodecyl sulfate-polyacrylamide gel electrophoresis for the separation of proteins in the range from 1 to $100 \mathrm{kDa}$. Anal. Biochem. 166: 368-379.

39. Cheung P, Banfield BW, Tufaro F. (1991) Brefeldin A arrests the maturation and egress of herpes simplex virus particles during infection. J. Virol. 65: 1893-1904.

40. Chatterjee S, Sarkar S. (1992) Studies on endoplasmic reticulum-Golgi complex cycling pathway in herpes simplex virus-infected and Brefeldin A-treated human fibroblast cells. Virology 191: 327-337.

41. Koyama AH, Uchida T. (1994) Inhibition by brefeldin A of the envelopment of nucleocapsids in herpes simplex virus type 1-infected Vero cells. Arch. Virol. 135: 305-317.

42. Dasgupta A, Wilson DW. (2001) Evaluation of the primary effect of brefeldin A treatment upon herpes simplex virus assembly. J. Gen. Virol. 82: 1561-1567.

43. Eggers M, Bogner E, Agricola B, Kern HF, Radsak K. (1992) Inhibition of human cytomegalovirus maturation by brefeldin A. J. Gen. Virol. 73: 2679-2692.

44. Gershon AA, Sherman DL, Zhu Z, Gabel CA, Ambron RT, Gershon MD. (1994) Intracellular transport of newly synthesized varicella-zoster virus: final envelopment in the transGolgi network. J. Virol. 68: 6372-6390.

45. Whealy ME, Card JP, Meade RP, Robbins AK, Enquist LW. (1991) Effects of brefeldin A on alphaherpesvirus membrane protein glycosylation and virus egress. J. Virol. 65: 1066-1081.

46. Doms RW, Russ G, Yewdell JW. (1989) Brefeldin A redistributes resident and itinerant Golgi proteins to the endoplasmic reticulum. J. Cell Biol. 109: 61-72.

47. Urbani L, Simoni RD. (1990) Cholesterol and vesicular stomatitis virus $G$ protein take separate routes from the endoplasmic reticulum to the plasma membrane. J. Biol. Chem. 265: 1919-1923.

48. Miller SG, Carnell L, Moore H-PH. (1992) Post-Golgi membrane traffic: brefeldin A inhibits export from distal Golgi compartments to the cell surface but not recycling. J. Cell Biol. 118: $267-283$.

49. Hammond C, Helenius A. (1994) Quality control in the secretory pathway: retention of a misfolded viral membrane glycoprotein involves cycling between the ER, intermediate compartment, and Golgi apparatus. J. Cell Biol. 126: 41-52.

50. Nuchtern JG, Bonifacino JS, Biddison WE, Klausner RD. (1989) Brefeldin A implicates egress from endoplasmic reticulum in class I restricted antigen presentation. Nature 339: 223-226.

51. Qiu Z, Tufaro F, Gillam S (1995) Brefeldin A and monensin arrest cell surface expression of membrane glycoproteins and release of rubella virus. J. Gen. Virol. 76: 855-863.

52. Maynell LA, Kirkegaard K, Klymkowsky MW. (1992) Inhibition of poliovirus RNA synthesis by brefeldin A. J. Virol. 66: 1985-1994.
53. Stannard LM, Himmelhoch S, Wynchank S. (1996) Intranuclear localization of two envelope proteins gB and gD, of herpes simplex virus. Arch. Virol. 141: 505-524.

54. Browne H, Bell S, Minson T, Wilson DW. (1996) An endoplasmic reticulum-retained herpes simplex virus glycoprotein $\mathrm{H}$ is absent from secreted virions: evidence for reenvelopment during egress. J. Virol. 70: 4311-4316.

55. Kousoulas KG, Bzik DJ, DeLuca N, Person S. (1983) The effect of ammonium chloride and tunicamycin on the glycoprotein content and infectivity of herpes simplex virus type 1. Virology 125: 468-474.

56. Pfeffer SR, Rothman JE. (1987) Biosynthetic protein transport and sorting by the endoplasmic reticulum and Golgi. Anпu. Rev. Biochem. 56: 829-852.

57. Lippincott-Schwartz J, Yuan LC, Bonifacino JS, Klausner RD. (1989) Rapid redistribution of Golgi proteins into the ER in cells treated with brefeldin A: evidence for membrane cycling from Golgi to ER. Cell 56: 801-813.

58. Lippincott-Schwartz J, Donaldson JG, Schweizer A et al. (1990) Microtubule-dependent retrograde transport of proteins into the ER in the presence of brefeldin A suggests an ER recycling pathway. Cell 60: 821-836.

59. Donaldson JG, Lippincott-Schwartz J, Bloom GS, Kreis TE, Klausner RD. (1990) Dissociation of a 110-kD peripheral membrane protein from the Golgi apparatus is an early event in brefeldin A action. J. Cell Biol. 111: 2295-2306.

60. Orci L, Tagaya M, Amherdt M et al. (1991) Brefeldin A, a drug that blocks secretion, prevents the assembly of nonclathrin-coated buds on Golgi cisternae. Cell 64: 1183-1195.

61. Pietschmann SM, Gelderblom HR, Pauli G. (1989) Compartment-specific immunolocalization of conserved epitopes of the glycoprotein $\mathrm{gB}$ of herpes simplex virus type 1 and bovine herpes virus type 2 in infected cells. Arch. Virol. 108: 1-17.

62. Roizman B, Furlong D. (1974) The replication of herpesviruses. In Fraenkel-Conrat H, Wagner RR (eds). Comprehensive Virology 3: Reproduction. DNA Animal Viruses. New York: Plenum; 229-403.

63. Fishman PH, Curran PK. (1992) Brefeldin A inhibits protein synthesis in cultured cells. FEBS Lett. 314: 371-374.

64. Avitabile E, Gaeta SD, Torrisi MR, Ward PL, Roizman B, Campadelli-Fiume G. (1995) Redistribution of microtubules and Golgi apparatus in herpes simplex virus-infected cells and their role in viral exocytosis. J. Virol. 69: 7472-7482.

65. Sodeik B, Ebersold MW, Helenius A. (1997) Microtubulemediated transport of incoming herpes simplex virus 1 capsids to the nucleus. J. Cell Biol. 136: 1007-1021.

66. Elliott G, O'Hare P. (1998) Herpes simplex virus type 1 tegument protein VP22 induces the stabilization and hyperacetylation of microtubules. J. Virol. 72: 6448-6455.

67. Holland DJ, Miranda-Saksena M, Boadle RA, Armati P, Cunningham AL. (1999) Anterograde transport of herpes simplex virus proteins in axons of peripheral human fetal neurons: an immunoelectron microscopy study. J. Virol. 73: 8503-8511.

68. Granzow H, Klupp BG, Fuchs W, Veits J, Osterrieder N, Mettenleiter TC. (2001) Egress of alphaherpesviruses: comparative ultrastructural study. J. Virol. 75: 3675-3684.

69. Skepper JN, Whiteley A, Browne H, Minson A. (2001) Herpes simplex virus nucleocapsids mature to progeny virions by an envelopment->deenvelopment->reenvelopment pathway. J. Virol. 75: 5697-5702. 